\title{
Intelectuales, ciencia y espiritualismos en los años de entresiglos. Intervenciones de Carlos Octavio Bunge, Emilio Becher y Leopoldo Lugones ${ }^{1}$
}

\author{
SOLEDAD QUEREILHAC Universidad de Buenos Aires - CONICET, Argentina / solquerei@gmail.com
}

\section{Resumen}

En los años de entresiglos en el Río de la Plata, intelectuales y escritores de orientaciones ideológicas diversas reflexionaron sobre la función, la imagen y las posibilidades de las ciencias en el marco de una nación en proceso de modernización. La cavilación sobre el lugar de las ciencias excedió, por cierto, los marcos de discusión del positivismo y se extendió hacia otras zonas de la cultura, como las corrientes espiritualistas modernas —el espiritismo y la teosofíaque llegaron al país hacia el último tercio del siglo XIX, y como la literatura fantástica de corte cientificista.

Buscando desarmar las anacrónicas polarizaciones entre espiritualismo y cientificismo, y atenta a la gran gama de grises que ofrece la cultura de entresiglos, en el presente trabajo propongo una revisión de una serie de textos ensayísticos y ficcionales de Leopoldo Lugones, Emilio Becher y Carlos O. Bunge que complejizaron el mosaico de gravitación del discurso de las ciencias. El elemento común a estas tres intervenciones fue la necesidad de preguntarse, de maneras diferentes, tanto sobre «el más allá» de los preceptos positivistas, como sobre la posibilidad de reunir en un marco disciplinar global lo que la ciencia moderna tendía a separar paulatinamente en áreas diferenciadas.

Palabras clave: espiritualismo / positivismo / intelectuales / fantasía científica / entresiglos

\section{Intellectuals, Science and Spiritualism at the turn of the twentieth century in Argentina. Essays and fictions by Carlos Octavio Bunge, Emilio Becher y Leopoldo Lugones}

Abstract

At the turn of the twentieth century in the Río de la Plata, intellectuals and writers of diverse ideological orientations thought about the function and the possibilities of Science in the context of a young nation. Their interventions took place beyond the frames of positivism, and developed in other areas such as the magazines of local Spiritualism and Theosophy, and the fantastic literature based on scientific topics.

Seeking to discuss the anachronistic polarizations between Spiritualism and Scientism, and being aware of the wide grayscale between both terms present in the turn of the century culture, in this work I propose to analyze a series of essays and fictional texts written by Leopoldo Lugones, Emilio Becher and Carlos O. Bunge. No matter whether Bunge claimed himself a positivist intellectual, whether Becher and Lugones were identified with Spiritualism and Modernism, in their texts they all sought answers for what was further of the limits of positivist methodology. Moreover, they dreamed, in different ways, about a sort of global discipline that could gathered the modern scientific knowledge and the spiritualistic believes, the moral and the Ideal.

Key words: spiritualism / positivism / intellectuals / scientific fantasy / turn of the twentieth century

Fecha de recepción: 6/12/2017; fecha de aceptación: 14/3/2018

Para citar este artículo: Quereilhac, Soledad (2018). «Intelectuales, ciencia y espiritualismos en los años de entresiglos. Intervenciones de Carlos Octavio Bunge, Emilio Becher y Leopoldo Lugones». El taco en la brea 7 (diciembre-mayo), 159-181 Santa Fe, Argentina: UNL. DOI: https://doi.org/10.14409/tb.voi7.7362 
En los años de entresiglos en el Río de la Plata, intelectuales y escritores de orientaciones ideológicas diversas reflexionaron sobre la función, la imagen y las posibilidades de las ciencias en el marco de una nación en proceso de modernización. La cavilación sobre el lugar de las ciencias excedió, por cierto, los marcos de discusión del positivismo y se extendió hacia otras zonas de la cultura del período, como las corrientes espiritualistas modernas -el espiritismo y la teosofía - que llegaron al país hacia el último tercio del siglo XIX, y como la literatura fantástica de corte cientificista.

En efecto, en los años del pasaje del siglo XIX al XX, es posible hallar en revistas de espiritistas y teósofos, tempranos (y poco conocidos) ensayos de los escritores Leopoldo Lugones y Emilio Becher, acerca de los alcances y límites de las ciencias y del positivismo, así como de la necesidad de incluir dentro de las pertinencias de una ciencia futura la dimensión espiritual de la vida. Años más tarde, Lugones volverá sobre ideas llamativamente similares tanto en sus relatos de Las fuerzas extrañas (1906) como en sus ensayos Elogio de Ameghino (1915) y El tamaño del espacio (1921), y esa similitud es signo de cuánta pregnancia ha tenido en el escritor el ideario teosófico, aún en sus ensayos relacionados con el nacionalismo cultural. ${ }^{2} \mathrm{Al}$ mismo tiempo, en inesperada sintonía pero desde un soporte periodístico diferente -el semanario ilustrado Caras y Caretas -, un intelectual de clara inscripción positivista como Carlos Octavio Bunge volcó en sus textos ficcionales de orientación fantástica inquietudes espiritualistas respecto de su credo científico, inquietudes que contrastaban con los argumentos de sus ensayos sobre psicología y sociología, de corte racialista y biologicista. Ficciones luego incluidas en el libro Viaje a través de la estirpe, de 1908, en ellas se escenifica una trastienda de pensamiento del intelectual positivista, donde los dilemas del determinismo biologicista hacen su descargo y las preguntas sobre la religión y lo sobrenatural encuentran su cauce.

Buscando desarmar las anacrónicas polarizaciones entre espiritualismo y cientificismo, y atenta a la gran gama de grises que ofrece la cultura de entresiglos, en el presente trabajo propongo una revisión de una serie de ensayos y ficciones de Lugones, Becher y Bunge que complejizaron el mosaico de gravitación del discurso de las ciencias en un país en construcción. El elemento común a estas tres intervenciones fue la necesidad de preguntarse, de maneras diferentes, tanto sobre «el más allá» de los preceptos positivistas, como sobre la posibilidad de reunir en un marco disciplinar global lo que la ciencia moderna tendía a separar paulatinamente en áreas diferenciadas.

A su manera, estos tres autores buscaron razonar una forma de monismo, tal como buscó una zona del positivismo, pero no supeditado a la física o la biología, sino basado en una disciplina superadora, que contemplara la dimensión espiritual. Bunge mostró su desazón respecto de esta síntesis en sus ficciones fantásticas (en contraposición a lo que intentó en sus ensayos sobre psicología), mientras que Lugones y Becher, cada uno a su modo, se entusiasmaron con la posibilidad de reunir en una disciplina de síntesis todas las preguntas sobre el conocimiento del mundo. En los tres, se halla el interrogante sobre los posibles enlaces del discurso científico, de corte positivista o no, con la ética, la espiritualidad, la religión, la construcción de una nacionalidad, la renovación de las creencias, entre otros ejes. También hallamos preguntas sobre cómo la ciencia avanza o retrocede frente a los objetos de estudio, y qué excluye hacia esa categoría spenceriana de lo «incognoscible». Y las respuestas, lejos de ofrecer argumentos concretos, fueron ante todo sintomáticas y proyectivas; sintomáticas de un malestar en el caso de Bunge, y proyectivas hacia una utópica solución futura en el caso de Lugones y Becher. 
Asimismo, se corrobora en estas intervenciones una marca distintiva, que acaso podría llamarse «idiosincrática» si se pasa por alto la desmesura léxica, de las especulaciones de corte espiritualista que ciertos intelectuales argentinos realizaron respecto de la ciencia. Se corrobora en los años de entresiglos una deriva, un permanente desvío hacia lo espiritual cuando se reflexiona sobre la ciencia desde una perspectiva cultural, cuando se piensa el lugar, la función y los alcances del desarrollo científico en la sociedad. Esto presupone una apropiación y una distorsión del discurso de las ciencias, así como de sus teorías, conceptos y leyes. Se detecta en estos textos, entonces, una espiritualización de las ciencias como condición previa para poder reflexionar sobre sus alcances y su función social. Es por ello que, en la perspectiva de análisis de este trabajo, se leerán estas intervenciones como ejercicios conjeturales, ejercicios de imaginación (no siempre autoasumidos como ficcionales) sobre una ciencia del futuro, sobre una ciencia espiritualizada o sobre una ciencia impotente ante el misterio. En todo caso, se trata siempre de encrucijadas provocadas por el propio protagonismo y por la enorme autoridad del discurso científico en esas décadas, que en cierto punto impiden pensar por fuera de sus parámetros y fomentan, entonces, peculiares esgrimas discursivas.

\section{Tres figuras distintivas del pasaje de siglos}

Si tuviéramos que identificar las ubicaciones de Carlos Octavio Bunge, de Leopoldo Lugones y de Emilio Becher dentro del ambiente cultural de principio de siglo XX, partiríamos de notables distinciones. Mientras el abogado Bunge se declara asentado en las filas de lo que a grandes rasgos dio en llamarse el "positivismo argentino», con sus escritos sobre psicología, sociología, educación y leyes enmarcados en la matriz biologicista, el escritor Leopoldo Lugones es ya un temprano referente de la literatura modernista y desde fines de siglo XIX, es miembro de la Sociedad Teosófica en Argentina, donde da una serie de conferencias a las que me referiré más adelante. Por esos años, Lugones adquiere un gran bagaje de conocimientos en la «biblioteca» teosófica, en la que confluyen tanto textos sobre religión y filosofía como sobre ciencias. Y es allí donde forja una idea de Ciencia con mayúsculas que se asume superadora de las limitaciones del materialismo positivista de su época. Por su parte, el más joven Emilio Becher es un adolescente en el pasaje de siglos y se inicia en la escritura en la revista espiritista Constancia, dirigida por su padrino, Cosme Mariño, años antes de convertirse en colaborador de la revista Ideas, de Manuel Gálvez y Ricardo Olivera, del diario La Nación a partir de 1906 y de otros medios de prensa. Becher se reconoce espiritista en esos años, pero sus colaboraciones para la revista lo muestran ya crítico con la zona más religiosa de esa doctrina y entusiasmado, en cambio, con las aspiraciones científicas del espiritismo, así como su articulación política con el socialismo.

Sus lugares de enunciación son diferentes, si bien es posible encontrar algunas matrices ideológicas comunes, sobre todo en Lugones y Bunge: ya sea por vías biologicistas de corte racista, ya por argumentos de superioridad espiritual, tanto Lugones como Bunge descreen de la democracia del sufragio universal y poseen la misma resistencia a considerar a las masas aptas para gobernarse a sí mismas, porque identifican la tarea de gobernar con las minorías ilustradas. Por su parte, Becher simpatiza en sus comienzos con un socialismo utópico más igualitarista, inspirado acaso en uno de los referentes del espiritismo francés, León Denis; pero luego, cuando ya forma parte de la redacción del diario La Nación, muestra un viraje hacia el nacionalismo cultural, tenuemente xenófobo. ${ }^{3}$ En los tres es posible detectar, entonces, la convicción elitista —ya sea por razones 
biológicas, espirituales o estéticas (o todas combinadas) — de que las jerarquías sociales expresan un ordenamiento necesario y justificado.

Lugones y Bunge, por su parte, encarnan dos figuras de intelectual contrapuestas en la época, que en cierto sentido se encuentran en disputa: por un lado, el intelectual escritor, legitimado por su obra literaria y sus funciones en el proyecto cultural del Estado liberal; y por otro, el intelectual cientificista, amparado en un saber disciplinar dentro de las ciencias sociales, que también cumple funciones estatales. Acaso baste recordar lo que Terán llamó el «operativo Lugones» del año 1913 (1993:46), cuando el poeta pronunció sus conferencias sobre el Martín Fierro de Hernández y definió, frente a la elite política y cultural, en qué consistía ser argentino, para tener presente el clima de disputa que existía entre esos dos modelos de intelectual cuando se ponía en juego la legitimación de uno u otro discurso para hablar de la sociedad y la cultura. De todas formas, se trata en ambos casos de intelectuales que, sin ocupar cargos políticos, llevaron adelante proyectos culturales y pedagógicos en el marco del gobierno conservador, y que se asumieron, a un tiempo, autónomos y al servicio de una política pública de conformación de la ciudadanía y/o de su estudio diagnóstico. ${ }^{4} \mathrm{~A}$ diferencia de estas dos figuras, Emilio Becher encarna al escritor modernista, con filiación en la bohemia y en el periodismo cultural del 9oo, que se resiste a concluir sus estudios de Derecho y que legitima su enunciación como escritor profesional en el incipiente proceso de profesionalización de la literatura y la conformación de un campo cultural. Su obra es ciertamente mucho menos vasta que la de los anteriores, y algunos de sus amigos, como Ricardo Rojas, suelen recordarlo como una gran promesa de escritor que nunca llegó a concretarse. ${ }^{5}$

Con todo, en cada uno de sus lugares de enunciación, es posible recuperar el eco de una inquietud similar, ante la cual se ensayan diferentes respuestas. En ese eco resuena el imperativo de pensar sobre todo aquello que, en un sentido amplio, queda en un «más allá» de los límites que el positivismo impone a las ciencias.

\section{El pesimismo decadentista de Carlos Octavio Bunge}

En su detallado estudio sobre la evolución del pensamiento de Bunge, Oscar Terán (2010) inscribe su obra en lo que denomina la "cultura científica» de los años de entresiglos y detecta en ella un ejemplo de las complejas reformulaciones del positivismo que se impusieron en la Argentina. La particular incorporación de los postulados positivistas en la obra de Bunge se caracteriza por una resistencia al mecanicismo spenceriano y una indagación en los terrenos de lo que Spencer denominaba lo «incognoscible», movido por su interés en la psicología. La imposibilidad propia del positivismo para formular una ética y unos valores colectivos capaces de cohesionar a una nación con alto porcentaje de población extranjera, junto con las limitaciones que imponía el mecanicismo para pensar la psiquis humana, fuerzan a Bunge a buscar en el terreno de los ideales y de la filosofía el complemento para sus teorías cientificistas. Así, para Oscar Terán, Bunge buscará respuestas mediante «una incrustación espiritualista en el interior de su credo positivista» (2000:141).

Bunge es el claro ejemplo de intelectual argentino que intenta una reformulación del positivismo desde adentro, que intenta amoldar los argumentos del socio-darwinismo a la coyuntura particular de la Argentina de esos años, y es a la vez uno de los más ricos ejemplos de las tensiones y las contradicciones que este enmiendo traía como consecuencia, sobre todo cuando se intentaba reunir en una misma doctrina el determinismo de la herencia con el poder transformador de la educación escolar estatal. Según Terán, el recorrido intelectual de Bunge confirma «las dificultades 
del positivismo criollo para elaborar un discurso homogéneo entre sus pretensiones científicas y sus intervenciones ético-políticas, en la disputa por proponer un modelo de identidad nacional para las masas. Ilumina, por fin, (...) las complejas relaciones entre el científico y el político que de esas dificultades debieron derivarse» (2000:206).

El punto de tensión más evidente en la producción de Bunge surge del cotejo de dos de sus obras, Nuestra América. Ensayo de psicología social (1903) y Nuestra Patria (1910): en el primer caso, se trata de un texto escrito para sus pares, en el cual indaga en clave racista las causas de la supuesta inferioridad de Latinoamérica frente a los pueblos anglosajones; como no podía ser de otra manera, el hincapié está puesto en la población indígena y africana que cargan «naturalmente» con la inferioridad tanto racial como moral. El segundo caso, Nuestra Patria, se trata de un manual escolar escrito para quinto y sexto grado de la escuela primaria, en el cual Bunge incluye al gaucho y al mulato como felices integrantes de nuestra nación. Aquello que escribe para sus pares de las ciencias sociales está plagado de ideología jerarquizante, elitista y racista; pero cuando debe dirigirse a los alumnos de las escuelas públicas argentinas, se ve en la obligación de transmitir valores más igualitarios e inclusivos, a la vez que busca construir un relato histórico con personajes atractivos. En este contraste, se pone en evidencia que los diagnósticos racialistas eran materia prima estéril para construir idearios nacionales que permitieran la identificación y la educación de la futura ciudadanía, en la medida en que postulaban exclusiones y condenas biológicas, psicológicas y morales sobre esa misma población que se buscaba educar.

Ahora bien ¿qué dilemas se reservó Bunge para la ficción? Paralelamente a las horas dedicadas a la pedagogía (El espíritu de la educación, 1901; La Educación, 1902), la psicología (Principios de psicología individual y social, 1903) y las leyes (El derecho, 1903; Historia del derecho argentino, 1912-1913), Bunge dedicó tiempo también a la literatura. Publicó libros de relatos, novelas y una obra de teatro. De entre ellos, se destaca Viaje a través de la estirpe, una compilación de relatos editada en 1908 en la colección de La Biblioteca de La Nación, una de las primeras empresas editoriales nacionales destinadas al creciente número de lectores, integrada en su mayor parte por títulos extranjeros, y en la cual pocos autores vernáculos publicaban. Cabe señalar, no obstante, que tres de los cuatro relatos incluidos en ese volumen habían sido publicados a comienzos de ese mismo año en el semanario ilustrado Caras $y$ Caretas, acompañados de ilustraciones: «Viaje a través de la estirpe» fue dado a conocer como folletín, en cinco entregas consecutivas, ilustradas de Peláez y firmadas con el pseudónimo de Thespis; del relato «La sirena» se dio a conocer el capítulo I, con el llamativo título «Una sirena en Mar del Plata!», acompañado de ilustraciones de Hohmann y firmado por Mario Delcos; por último, el relato breve «Un valiente» apareció sin pseudónimo. Esto demuestra que, inicialmente, estas ficciones fueron pensadas para un público masivo y que sólo en segunda instancia pasaron al formato de libro. Es curioso también el uso del pseudónimo en el marco de Caras y Caretas, y la plena asunción de autoría en la colección de La Nación. A diferencia de Horacio Quiroga, por ejemplo, que sólo utilizó el pseudónimo en Caras y Caretas cuando publicó sus novelas cortas en la sección del folletín, a causa quizás del menor valor literario que él hallaba en esas historias truculentas, llenas de intriga y suspenso, Bunge pareció usar el pseudónimo para no blanquear su paso por un semanario ilustrado.

Como sea, tanto en «Viaje a través de la estirpe» como en "La sirena», el autor concibió narraciones fantásticas profundamente atravesadas por dilemas y tensiones presentes en su obra ensayística. Junto con títulos como «La psiquina» de Ricardo Rojas (La Nación 1906), «El Psychon» (Tribuna 1898) y «La licanthropia» (Philadelphia 1898), «El almohadón de plumas» (Caras y Caretas 
1907) o «La gallina degollada» (Caras y Caretas 1909) de Horacio Quiroga, «El daño» (La Nación 1907) de Atilio Chiappori, entre muchos otros, estos relatos de Bunge se incluyen dentro de esa modalidad del fantástico propio del periodo de entresiglos: la fantasía científica o temprana ciencia ficción, cuyas características distintivas fueron la incorporación de teorías, descubrimientos y/o temáticas científicas de la época con las cuales se proyectaba una deriva fantástica, y la cercanía del espacio-tiempo y de las referencias culturales con el mundo contemporáneo de los lectores (esto es, la inserción de la fantasía en el aquí y ahora de quien lee). ${ }^{6}$ Asimismo, en relación con el propio proceso de autonomización de la literatura, en el que la prensa gráfica que incluía textos literarios jugó un rol fundamental, se verifica en estos relatos una cercanía con los recursos de enunciación del periodismo, así como la emulación de sus estrategias de veracidad, adaptadas a la verosimilitud literaria.

En «Viaje a través de la estirpe», Bunge reflexiona sobre algunos de sus desvelos, como por ejemplo, el peligro de degeneración de la especie humana producto de su inteligencia y de los artificios de la civilización, un temor que era compartido por diferentes esferas de la cultura finisecular pero que en Bunge encuentra vertientes decadentistas. Asimismo, el relato incluye otros temores en clave cientificista: el resurgir de la animalidad en el hombre, tema también trabajado por Lugones y Quiroga en sus ficciones, aunque con perspectiva diferente; la igualdad o desigualdad entre las razas, homologadas a la posición social; lo «incognoscible» spenceriano, reinterpretado en clave cristiana como los misterios de dios.

El narrador de esta historia es Lucas, un médico nieto de hidalgos de Castilla e hijo de patricios en América, que está a punto de perder a su esposa, Teresa, hija de sirvientes. El médico siente una profunda culpa frente a su esposa por haberle reprochado reiteradas veces, en ataques de furia, que su linaje plebeyo es la causa de la degeneración moral de sus cuatro hijos. Como Lucas posee distinguidos ascendientes, la única razón por la cual sus hijos se hayan convertido en alcohólicos, vagos e iletrados es la herencia «inferior» que les legó su plebeya esposa. Una discusión marital en términos similares aparecerá también en un relato publicado al año siguiente en Caras y Caretas por Horacio Quiroga, «La gallina degollada», aunque su resolución estética y narrativa serán muy diferentes, y los acontecimientos apuntarán en otra dirección, esto es, al efecto propio de un relato de horror con el que el lector se sienta conmovido e interpelado, y no a la postulación de una tesis como en Bunge. De todos modos, esta coincidencia, junto con otras, da cuenta de la vigencia del tema de la herencia y el temor a la degeneración en la época.

En el lecho de muerte, Teresa, que es una férrea creyente católica, le transmite a su esposo su último deseo: «que Dios te ilumine antes de que abandones la tierra, y te demuestre, con tu propia ciencia, que no es mi humilde cuna la causa de la miseria de tus hijos» (1908:14). Efectivamente, el deseo de Teresa se cumple, y en una especie de ensueño fantástico, Lucas es trasladado de la mano de la moribunda a un reino celestial, en el cual se encuentra con dos personajes: Asrael, el Ángel de la Muerte y de Agonía, especie de guía que lo conduce hacia el encuentro de un señor barbudo a quien Lucas confunde con el mismo Jehová, pero que no es otro que Charles Darwin. Se trata de un Darwin «celestial» dispuesto a satisfacer los deseos de Teresa y guiar a Lucas a través de su estirpe para probarle que no fue la herencia de su esposa la causante de la degeneración de sus hijos, sino, en todo caso, la de ambos por igual. El relato avanza en una serie de cuadros que, proyectada «en la cinta de un gigantesco cinematógrafo» (20), ilustra las diferentes fases de la formación del universo hasta llegar a los primeros hombres primitivos. Escrito con una prosa 
recargada y patética, «Viaje a través de la estirpe» es, en realidad, un cuento de tesis, que no busca tanto contar una historia por su atractivo narrativo, sino argumentar una idea por medios alternativos a los del ensayo.

El hilo conductor de este viaje (un verdadero descenso a los infiernos) ancla en el tópico decadentista de la degeneración. Darwin se complace en identificar a los ancestros de Lucas en cada uno de los moluscos, bestias o monos salvajes que se gestan en cada una de las etapas evolutivas, y con ello el relato traza valoraciones decadentistas respecto de las adquisiciones superiores del hombre, como la inteligencia y la civilización. Por ejemplo, comparada con la monogamia natural del primitivo hombre-mono, el «desafuero sexual» y la «promiscuidad» del hombre-civilizado se presentan como una perversión de «las sanas costumbres animales», al tiempo que la inteligencia, vista como «una manifestación enfermiza de la vida», sería la responsable de la decadencia de las civilizaciones, al apartar al hombre de su curso natural de vida $(85,88)$. «La humanidad será pronto decrépita si sigue su evolución", afirma Darwin, con lo cual biología y cultura, instinto y civilización se presentan así como polos irreconciliables (88); tal es la encerrona a la que nos va llevando este relato.

Este clima de desencanto derivará finalmente en la verdadera «lección» del celestial Darwin, cuando sorpresivamente concluye:

Como has visto Lucas, los hombres descendemos de las más bajas formas de la animalidad. Es, pues, injusto y torpe el sentimiento de los aristócratas que se enorgullecen de su origen. Tu plebeya esposa Teresa no tuvo peores ascendientes que los tuyos. Todos los hombres somos hermanos. Hasta diría: jtodos los animales somos hermanos! (89)

La sentencia desconcierta en pluma de un intelectual positivista tan preocupado por justificar racialmente, en sus ensayos, las "naturales» y necesarias diferencias en la población argentina. Podemos decir que la ficción fantástica le sirve a Bunge para enunciar en otro registro, el registro de la literatura, un escollo de su propio pensamiento, la sospecha de que el discurso determinista de la herencia obtura todo intento de transformación de la realidad y confirma, por vías inesperadas, que el pesimismo de los decadentes tiene un valor de verdad. Por otro lado, su fantasía también tramita la desilusión que una teoría como la de Darwin provoca en quienes ven superioridad espiritual en el hombre respecto del resto los animales. Terán señala que hay «un punto donde el decadentismo se comunica con el positivismo: el referido a la idea de la degeneración de la raza, con cuyo reforzamiento el cientificismo aportaba nuevos motivos para el pesimismo» (2010:166) El relato de Bunge sin dudas monta su fantasía sobre esa confluencia.

En efecto, Bunge viene a coincidir con Lugones y otros modernistas en relación con el diagnóstico de decadencia de una civilización, aunque no así en la valoración de esa decadencia. Unos años antes, en 1897, en La Quincena. Revista de Letras, un órgano de escritores modernistas y ensayistas afines, dirigido por Guillermo Stock, Lugones había escrito sobre «Los climas del arte» (una de sus primeras intervenciones en Buenos Aires) y afirmaba:

En toda decadencia se ve despuntar siempre un filósofo o un poeta: siempre un vidente. El Arte tiene sus climas históricos propicios, fuera de los cuales no florece. Para mí el clima del Arte es la decadencia, toda decadencia. (...) 
Ahora bien: no se puede buscar el arte en la salud, porque es un histerismo trascendental. (...) Sí, los artistas son degenerados, pero su degeneración es de esas que denuncian un principio de selección favorable en la humanidad, como decía el sabio suizo Augusto Fovel en el último congreso de antropología criminal en Génova. (Lugones 1897-1898:310-311)

Lo que en Bunge es acaso la sublimación de una angustia irresoluble, producto de su mismo esquema de pensamiento, en Lugones es celebración esteticista, idealista y mística del tiempo del Arte. Y en ello se permite, incluso, hacer uso de una cita de autoridad científica para afirmar la verdadera «evolución» que implica la decadencia y la degeneración.

En la ilustración de Peláez que acompañó la última entrega de «Viaje a través de la estirpe» es posible hallar, en efecto, el retrato del protagonista completamente solo, tomándose la cara con sus manos, en una actitud de desesperación. Si a lo largo de las entregas había predominado la recreación de escenas - Darwin y Luis conversando, una mujer-mono cuidando a sus crías, una cacería de búfalos, etc. - en la última se enfatiza a través de la ilustración la contracara de la enseñanza igualitarista del Darwin celestial: la conciencia de saberse parte de una «estirpe» en decadencia, en vías de degeneración y en pie de igualdad con los plebeyos.

Por otro lado, y en otra dirección, se observa que el acatamiento del Darwin personaje a los designios de Dios deja leerse como una concreción sintética de lo que Bunge intentaba realizar en sus ensayos: encontrar una conciliación y una complementariedad entre la utilidad del saber científico y una ética de valores colectivos que, con la introducción de conceptos como la voluntad y el deber-ser, lograra paliar la construcción demasiado bestializada del individuo. En el relato, en efecto, aparecen propuestas de complementariedad de saberes. Darwin afirma que «hay un fondo de verdad eterna", una "unidad de la verdad", en todos los mitos y pensamientos humanos» (1908:27) esto es, en todas las religiones del pasado y del presente, al tiempo que acota los alcances de su teoría evolutiva:

Ni por un momento, al exponer el origen de las especies, creí haber resuelto la Causa de las Causas. La gran incógnita persiste siempre y lo Incognoscible no será conocido. De ahí que coexistan siempre dos mundos; el de los fenómenos y la ciencia, el humano y el de los mitos y la religión, el superhumano. ¡Ya ves cómo no nos excluimos ni chocamos, yo, el naturalista Darwin y Asrael el arcángel! (32)

Bunge pone en boca de Darwin la categoría spenceriana de los incognoscible, y si bien es cierto que Darwin, en su libro de 1852, elude la explicación del origen de la vida e insinúa la creación divina, el autor se toma estas licencias ficcionales para espiritualizar el marco que rodea a la teoría del naturalista. Asimismo, es posible arriesgar que vela aquí, a pesar del declarado ateísmo de Bunge, una matriz católica, que pone a Dios como Causa primera y última de la vida. Acorde al testimonio de Manuel Gálvez, Bunge se convirtió definitivamente al catolicismo antes de morir (378). ${ }^{7}$

Todo «Viaje a través de la estirpe» es sintomático de una contradicción de ideas y argumentos: si la conclusión es igualitarista en una forma pesimista, no faltan, sin embargo, sentencias jerarquizantes, racistas y elitistas en otros tramos; si en ocasiones se afirma la existencia de Dios y se defiende la metafísica, en otros el narrador dice que «dios» es una invención de la psicología del hombre. En este sentido, el texto constituye un notable documento sobre la trastienda del 
pensamiento de un intelectual que oscila entre su «voluntad» de positivismo y su tambaleante marco teórico para las disciplinas sociológicas.

Ahora bien, en el relato «La sirena», aparecen similares dilemas en torno a las limitaciones del discurso científico como organizador de saberes y creencias de una comunidad. El relato transcurre inicialmente en Mar del Plata, en un enero de comienzos de siglo, y luego la acción se traslada a las Islas Malvinas (en ese momento, territorio británico) y a Buenos Aires. Bunge narra allí el encuentro de un periodista diletante con una auténtica sirena, que en principio lo enamora y obnubila con su canto hipnótico pero que, luego, en una vuelta de tuerca cientificista de la leyenda, le habla en términos muy racionales sobre su condición animal y repugnante. Después de salvarle la vida en un arrojo de filantropía animal, la sirena pierde todo su encanto y es descripta por el narrador como un «monstruo, con su largo apéndice natatorio, con su coriácea piel de delfín, con su aspecto fiero y silvestre», que sonríe "con horrible sonrisa de perro", que posee dientes "propios de una fiera carnívora» (1908:103), «uñas como garras» $\mathrm{y}$ «rugosas membranas» entre los dedos (107). La degeneración también afecta a su especie y ello es enunciado en los habituales términos machistas de Bunge: «como toda raza degenerada produce hembras superiores a sus machos», en referencia a los tritones (106). Pero lo más destacado en este relato es, como en el anterior, la tesis o argumento que busca postular por vía de la ficción. Y esa tesis se refiere a la imposibilidad del discurso científico para reemplazar las creencias e ilusiones que destruye, para ocupar el lugar del Ideal.

La primera vez que el protagonista y la sirena se ven cara a cara, ésta le dice:

El canto de la sirena atrae por el amor al misterio, a lo desconocido, al infinito... Es así que, una vez revelado ese misterio, ese desconocido, ese infinito, tal amor debe apagarse. ¡Confiésalo! ¿No es verdad que, una vez que me has visto de cerca, una vez que conoces mi verdadera existencia animal, has dejado de quererme con tu antigua ansia de muerte? (107)

La argumentación prosigue en un segundo momento del relato, en el que, capturada la sirena en las aguas del sur y llevada al gabinete del director del Jardín Zoológico de Buenos Aires, ella cuestiona:

¿qué provecho de felicidad puede aportar a los hombres el conocimiento científico de esta especie animal que ellos llaman «Sirena» y que ya conocen por la leyenda? (...) un desengaño es lo que sufrirá la humanidad si su ciencia me estudia y analiza, nada más que un desengaño. (...) Mi pérdida será una desilusión, la muerte de una de las más hermosas leyendas de los hombres. (133-134)

Aquí, el conocimiento científico es visto desde un punto de vista pesimista, hasta oscurantista si se quiere, porque el mensaje apunta no ya hacia el lamento por los límites infranqueables de lo Incognoscible, sino que, por el contrario, se exalta aquí el no-saber como forma de resguardo de las creencias, del mito, de la ilusión y el ideal. En línea con las palabras del Darwin celestial de «Viaje...», se postula aquí que la ciencia debe convivir con las leyendas y los misterios, y no avanzar sobre ese terreno. En efecto, la sirena le advierte al narrador que, entregándola a la ciencia, abandonándola en el laboratorio del Zoológico: «Procederás como un chico inconsciente, que rompe un precioso juguete para ver qué hay adentro. ¡El juguete es aquí el Ideal!» (134). Para este melancólico Bunge, conocer es sinónimo de desengaño, no de emancipación. Nuevamente en este relato, que 
logra acaso mayor desarrollo propiamente narrativo que el primero, es el síntoma de un malestar el que aflora: el malestar de un intelectual que no logra encontrar el punto de síntesis entre sus adscripciones al positivismo y sus inquietudes espiritualistas.

\section{El optimismo espiritualista de Emilio Becher}

En contraposición a esta visión decadente y pesimista, el joven escritor Emilio Becher expuso en sus colaboraciones para Constancia un entusiasmo en cierto punto cándido por el futuro de las ciencias y, sobre todo, por su capacidad de aunar el crisol de conocimientos y creencias en un marco de síntesis superador. Ana Lía Rey ve en el Becher de sus primeros pasos en Constancia a un «predicador-laico», que forma parte de esos «jóvenes liberales que transmiten su fe en la ciencia y en un porvenir esperanzador» (5).

Emilio Becher comenzó a escribir para Constancia a los diecisiete años, cuando todavía cursaba el último año en el Colegio Nacional de Rosario (ciudad a la que debió trasladarse su familia por un tiempo y desde donde envió sus primeras notas). Ahijado de Cosme Mariño, y presentado como tal en el anuncio con que la redacción le dio la bienvenida (Constancia, 18/o9/1898), Becher se asumía como espiritista, aunque desde su primera colaboración manifestó también interés por la teosofía. El joven colaboró en la revista de su padrino durante cinco años consecutivos y, a partir del 26 de agosto 1900, fue nombrado subsecretario de redacción.

Su adhesión al espiritismo fue incentivada por la filiación de su propio padre, Enrique Carlos Becher, a los primeros círculos espiritistas del país. Su padre fue amigo de Francisco Casares, un médium y fundador del grupo originario de la Sociedad Constancia en Buenos Aires, quien eventualmente lo introdujo en el movimiento. Enrique Carlos tenía una sólida formación protestante, pero a raíz de aquella amistad comenzó a participar también de grupos de experimentación espiritista tanto en Buenos Aires como en la ciudad de Dolores, junto a Cosme Mariño, futuro director de Constancia, a partir de 1880, y a Rafael Hernández, hermano del autor del Martín Fierro, entre otros (Cárdenas y Payá:34). El protestantismo de la familia Becher no es un dato menor, en la medida en que explica no sólo el conocimiento de Emilio de la tradición cristiana, sino también su compatible acercamiento al espiritismo, algo imposible para un católico dogmático.

Becher se diferenciaba del más pedestre perfil intelectual del resto de los integrantes de Constancia por la variedad de sus lecturas y por su estilo para escribir. En sus comienzos, publicó artículos sobre los temas de la cultura del fin de siglo: el caso Dreyfus en Francia y los problemas del antisemitismo; la figura modélica de Emile Zola; la paz armada en Europa y el clima de tensión con el socialismo; el catolicismo y la Iglesia como nefastos enemigos del siglo; la celebración del cosmopolitismo porteño y los peligros del avance anglosajón sobre Latinoamérica; entre otros. Y hacia 1900, comienza a criticar la reproducción de dogmas y creencias irracionales del espiritismo, características de las iglesias que decía combatir, así como la acrítica incorporación del cristianismo como médula moral. El centro del problema radicaba, para Becher, en la obra misma de Allan Kardec, leída como catecismo (1900a:299-300).

Lector tanto de Herbert Spencer como de Max Nordau, Becher argumentaba que «el espiritismo Kardeciano disolvió la admirable leyenda del Cristo, Hijo de Dios, la sustituyó con una nueva leyenda, más verdadera, más real, no menos dulce y bella. Ahora sólo se trata de sustituir a su vez esa fábula con una explicación verdaderamente científica» (1902:276). Su concepto de ciencia era ciertamente integral, extendido tanto al campo de lo natural como de lo social, y guiado por la 
fuerte convicción sobre su poder emancipador para la humanidad. Para Cárdenas y Payá, el joven Becher de esta etapa:

era un convencido de la verdad científica. Su espíritu profundo lo inclinaba decididamente hacia lo misterioso, pero esto no lo llevaba todavía a dar el gran salto que su vida intelectual le deparaba. Intentaba conciliar lo invisible y la ciencia; es uno de los muchos que buscaban hacia el 1900 ensanchar el campo del saber experimental para que iluminara también las zonas oscuras y espirituales de la realidad. De aquí su espiritismo, de aquí su orientación hacia la teosofía, de aquí también sus estudios de exégesis bíblica y de historia de las religiones. (40)

Estas convicciones estaban a tono con lo que el espiritismo occidental, tanto de corte kardeciano como anglosajón, sostenía respecto de su posible articulación con el campo científico. En efecto, en las páginas de Constancia, editada por primera vez en 1877 y de larga vida durante el siglo $\mathrm{XX}$, es posible hallar una original y sintética empresa de divulgación, apropiación y alteración del discurso científico cuyo objetivo era hacer ingresar las prácticas espiritistas dentro del amplio campo de «lo científico». De salida quincenal en esos años del pasaje de siglos, financiada tanto por suscripciones como por el aporte de los socios más acaudalados, en Constancia era frecuente encontrar la reseña de los últimos descubrimientos científicos e innovaciones tecnológicas - los nuevos rayos; la invención del telégrafo sin hilos y del teléfono; la licuación de gases; el aislamiento de microbios; entre muchos otros- y en contigüidad a esta cobertura, se exponían los argumentos que afianzaban la idea de que, si lo otrora considerado imposible o inexistente estaba cobrando realidad gracias a la investigación científica, pronto la «materialidad» del espíritu, la «fuerza» de la mente, la transmisión del pensamiento o la transmigración de las almas a otros planetas iba a convertirse en materia revelada y explicada científicamente.

Entre los miembros de Constancia, velaba la convicción de que los fenómenos espiritistas constituían auténticos objetos de estudio científico, sólo que para que ello pudiera cumplirse cabalmente, la ciencia positivista debía hacer más laxas sus prerrogativas metodológicas. Lejos de instalarse en las filas de un anti-cientificismo reaccionario, los espiritistas buscaban encarnar los cimientos de una ciencia futura, que superara los escollos y limitaciones del positivismo. Así, en una de las notas editoriales de 1901, puede leerse:

El espiritismo y la ciencia positiva conocida hasta hoy no son dos sistemas de conocimiento opuesto el uno al otro: es la misma ciencia que se alecciona y se complementa, que se orienta y toma nuevos bríos (...)

El espiritismo fue, en un principio, desechado en absoluto, ridiculizado y tenido como un delirio, una fantasía de mente desequilibrada; una nueva forma del fanatismo religioso, un resurgimiento de lo sobrenatural y maravilloso, que la ciencia positiva creyó haber enterrado para siempre. Más tarde, y a medida que la misma tenacidad y multiplicidad de los fenómenos atraían, velis novis, la atención de muchos sabios sinceros y de conciencia esclarecida, se empezó a ver claro y a comprender que detrás de la danza de las mesas y de la tiptología de los trípodes, se ofrecía al observador imparcial y pertinaz un objeto digno de estudio: se presentaba un sistema científico cuyas leyes empezaban a descubrirse; y todo esto, siguiendo estrictamente el método de la ciencia positiva; sin salir de la observación y los hechos.

Entonces, empezó a verse que el espiritismo era la ciencia misma positiva, proyectándose más allá de los límites de los sentidos corporales; era una nueva faz de la ciencia misma, que aparecía en el momento 
en que, atrapada en un callejón sin salida, le era necesario tomar otra dirección o permanecer estacionada. («El espiritismo y la ciencia oficial», 24/11/1901)

Se ve aquí un intento de trazar una continuidad entre el quehacer científico y los intereses de los espiritistas, que configura otro modo de proyectar una ciencia "posible». Pero esa proyección no se detenía en este plano, sino que también fue posible hallar en Constancia una propuesta curiosamente similar, a grandes rasgos, a la del positivismo comteano, con una sutil diferencia: $\mathrm{si}$ éste proponía a la ciencia como la única capaz de proveer las nuevas «creencias» que reemplazarían a la religión, Emilio Becher veía en el espiritismo a la más perfecta síntesis superadora de las religiones dogmáticas, en la medida en que lograría «probar» la existencia del más allá.

Es así que, a propósito del «balance del siglo» que Becher trazaba en uno de sus artículos, no sólo aparecía la usual loa a la antorcha científica del siglo que finalizaba, ${ }^{8}$ sino que además esta celebración se extendía hacia una proyección futura sobre el avance de la ciencia por los terrenos de lo espiritual; el autor imaginaba la culminación del poder emancipador de las ciencias cuando éstas lograsen, con éxito, reemplazar a la religión y asegurar a la humanidad —no ya por la fe, no ya por el dogma, sino por la demostración— que la vida en el más allá era posible:

\footnotetext{
Y todavía parece que quisiera ir más adelante la ciencia, penetrando no sólo en el hortus conclusus del arte, sino en los más ásperos senderos, en plena selva salvaje de la religión. Los fenómenos del magnetismo, del sonambulismo y de la exteriorización del pensamiento han abierto, más allá de la fisiología, un mundo de fuerzas no sospechado, una sucesión indefinida de plano, hasta el último horizonte de lo suprasensible. Quisiera ser independiente, no inclinarme a ninguna escuela. Pero sería admirable y verdaderamente digno de la ciencia que, después de haber arrancado de nuestras almas hasta la última esperanza, fuera ella la que restaurara la fe y la que nos devolviera la certidumbre de una existencia inagotable y la superior alegría de la inmortalidad. (1901:419)
}

Becher piensa en una ciencia integral, en una «síntesis de todas las conquistas dispersas del positivismo moderno", que también va a corresponderse, en el plano económico, «en la unidad de todos los hombres en un colectivismo universal de fuerzas», esto es, el socialismo (419). En contraposición a la espiritualización excluyente de Lugones que, como veremos, busca absorber a las ciencias dentro del mosaico teosófico, y en contraposición también al desencanto de Bunge, que sólo ve antagonismo entre la ciencia y la religión, Becher sueña con una ciencia total que, acorde al sueño de los espiritistas, aunque extremándolo, pueda superar los oscurantismos, las religiones y el irracionalismo, y pueda reconciliar a la humanidad con las creencias por una vía razonada y aun, empírica (1900b:410).

Becher escribe en Constancia hasta 1903, si bien Cosme Mariño afirma que en años posteriores envió colaboraciones con pseudónimo (1963:212). Sus biógrafos, Cárdenas y Payá, aseguran que también colaboró con la revista espiritista Lumen, de Barcelona (35). Ricardo Rojas agrega, por su parte, que luego de su paso por Constancia, frecuentó la Sociedad Teosófica de Buenos Aires (1938:28), de la que, como adelantamos, era miembro Leopoldo Lugones, entre otros jóvenes intelectuales (como Alfredo Palacios). Lo cierto es que sus intervenciones públicas se orientan mayormente, a partir de estos años, hacia la literatura y la crítica cultural, acorde también a las nuevas empresas periodísticas a las que se incorpora, como el diario La Nación, en el que trabaja 
hasta su temprana muerte, en 1921. En ese diario, en efecto, publica una reseña de Borderland (1907), el libro de relatos de su íntimo amigo, Atilio Chiappori, en el que ya en sede de crítica literaria, Becher vuelve a celebrar la fusión del misterio con la ciencia, y el abordaje de fenómenos «invisibles» con métodos científicos:

[La novela «Un libro imposible»] es un caso curioso de ruina de la personalidad cuya explicación correspondería a las conjeturas de la clínica tanto como a la hipótesis del ocultismo. Ciertas experiencias del doctor Luys o del coronel De Rochas pueden ayudarnos a comprender las tentativas arriesgadas sobre su propio espíritu y sobre el de Anna María por Augusto (...) Ambos penetran en la zona del más allá y abordan el mundo habitado de lo sobrenatural. Sus formas prestan albergue al número infinito de los espíritus astrales y en sus semblantes se hace visible la presencia de las entidades ocultas. (1907:5)

Alejado ya sus intervenciones en Constancia, Becher rescata una narrativa de orientación fantástica que se interna por los senderos científico-ocultistas que él mismo exploró como deseo utópico en sus ensayos. Rescata ahora la reelaboración ficcional de un ideario que poco tiempo atrás había articulado sus creencias. Becher no volvió a intervenir en estas materias y de a poco su producción se fue estancando, hasta decantar en el mito del escritor «que no fue» que fomentaron sus contemporáneos (Sarlo y Altamirano:92; Dalmaroni:153-163). Con todo, sus años en Constancia dejan testimonio de sus ejercicios conjeturales sobre la ciencia del porvenir, un curioso ejercicio de fe en el progreso científico.

\section{Leopoldo Lugones y su espiritualización de la ciencia}

Entre los teósofos de Buenos Aires, aunados en la revista Philadelphia (1898-1902), también velaba una idea similar respecto de la pertinencia científica de la teosofía, aunque sus ambiciones eran aún mayores a la de los espiritistas. En Philadelphia, ya sea en los ensayos de los escasos autores argentinos como Leopoldo Lugones o el geógrafo Alejandro Sorondo (líder de la Rama Teosófica «Luz», la primera de Sudamérica), o en la reproducción de conferencias y partes de libros de los referentes del movimiento, como Helena P. Blavatsky o Annie Besant, la ciencia aparecía invariablemente en letra mayúscula, porque no remitía a las disciplinas modernas occidentales, sino al cúmulo de conocimientos esotéricos y exotéricos de Oriente y Occidente, del que la ciencia positiva era sólo un pequeño capítulo. A diferencia de los espiritistas, los teósofos no buscaban encarnar una ciencia del futuro, ni reemplazar al positivismo, tal como se vio en la cita precedente. Ellos postulaban, en cambio, una lógica temporal inversa: la ciencia positiva o materialista del siglo XIX venía a corroborar empíricamente lo que la teosofía ya sabía por vía de la revelación, la intuición de los clarividentes, el acervo de conocimientos cifrados en la mitología, la tradición esotérica de las religiones occidentales y orientales, entre otras fuentes. En esa línea, en Philadelphia se publicaron entre 1899 y 1900 numerosas entregas de las «Corroboraciones científicas de la teosofía», del brasileño João Benedicto de Azevedo Marques, en las que se tomaba cada uno de los avances científicos de los últimos años en materia de bacteriología, astronomía, radiación, entre otros, y se afirmaba que en La Doctrina Secreta (1888) de Blavatsky ya estaban prefigurados esos descubrimientos.

La teosofía se concebía a sí misma comola síntesis de todas las tradiciones religiosasy filosóficas, y contemplaba dentro de sus objetivos principales el estudio «científico» de los fenómenos espirituales; a su manera, también buscaba como los espiritistas algún grado de legitimación como 
productora de conocimiento científico, pero proponía al mismo tiempo absorber a la ciencia dentro de la Ciencia Teosófica. Se proponía, en síntesis, la utópica tarea de espiritualizar la ciencia, de darle un fin y un principio filosóficos, de darle un marco cosmogónico. La teosofía soñaba, también, con una extraña forma de monismo, idea tomada del positivismo comteano. Así parece afirmarlo Arthur Arnould, teósofo francés director de la revista Lotus Bleu, en «Ciencia teosófica»:

La Teosofía no es ni una religión nueva o antigua, ni un sistema metafísico que repose sobre los razonamientos o los sueños de un cerebro humano más o menos bien dotado. Es una ciencia, o más bien dicho, es la ciencia, toda la ciencia, la sola y única ciencia, es decir, la síntesis de la sola, única y eterna verdad, encerrando en su seno y poniendo de acuerdo todas las religiones, todas las filosofías y todas las ciencias, absorbiendo y disolviendo a la vez el deísmo, el ateísmo, el materialismo y el espiritualismo, por esta razón sin réplica, de que en lo absoluto todas las antinomias se resuelven (...). La Teosofía es la ciencia que nos enseña a distinguir la realidad absoluta de la ilusión relativa. De esto resulta, que siendo la teosofía la ciencia, todo lo que ella afirma puede y debe ser demostrado. Por esto, difiere de las religiones y filosofías ordinarias. (1898:18)

Una firma importante de Philadelphia fue la de Leopoldo Lugones. En su doble rol de poeta y de teósofo, buscó argumentar una articulación premoderna y monista del arte con la filosofía y la ciencia. Lugones se incorporó a la rama «Luz» en $1898,{ }^{9}$ y es en este marco de iniciación que no sólo comenzó a escribir sus primeros relatos fantásticos, muchos de los cuales integrarían luego su libro Las fuerzas extrañas (1906), sino también una serie de ensayos (inéditos aún en libro) en los que fijó argumentos sobre ciencia, religión y estética que retomaría en sus textos del Centenario, como Prometeo (1910), El payador (1916) y Elogio de Ameghino (1915), así como también su insólito El tamaño del espacio (1921), en el que espiritualiza ideas de Albert Einstein.

En los títulos de tres de sus cuatro ensayos publicados en la revista de los teósofos, aparece el pronombre «nuestro»: «Nuestras ideas estéticas», «Nuestro método científico», «El objeto de nuestra filosofía", signo de su expresa pertenencia al movimiento. Cabe señalar, además, que su adhesión al ideario teosófico parecía gozar de público conocimiento en Buenos Aires y testimonio de ello es la caricatura que Carasy Caretas publicó en el número de su primer aniversario; a diferencia del resto de los colaboradores caricaturizados, cuya apariencia humana se reprodujo fielmente, a Lugones se lo representó con pechos de mujer, cuerpo de sirena, brazos de león y alas de mariposa, mientras que en el texto se leía: «No es poeta para multitudes ni escritor para el vulgo, porque ama el lenguaje esotérico, y su ideal se oculta, bajo poder de encantamiento al pie de un dolmen, entre ruinas mitológicas» (7/10/1899).

Ahora bien, en el primer ensayo que escribe para Philadelphia, "Acción de la teosofía», Lugones anunciaba un cambio histórico en el pasaje de siglos: el avance del espiritualismo en las disciplinas científicas, en reemplazo de las caducas teorías materialistas:

De algunos años a esta parte estamos en plena reacción espiritualista. Después de su momento de triunfo, el Positivismo decae; la religión de la Humanidad sufre el efecto de su propio contrasentido, y esta tentativa de culto ateo sirve apenas para demostrar cuán inconsistentes son todos esos templos que la razón misma eleva, si no tienen por base una afirmación de fe. (1898a:167) 
Libre de la sumisión a toda iglesia tradicional, el espiritualismo estaba ingresando — según Lugones- al ámbito de la Ciencia, conduciéndola lentamente hacia la formulación de interrogantes antes prohibidos por la fobia metafísica: el por qué y para qué de los fenómenos de la vida. El modelo de esta nueva ciencia estaba, paradójicamente, en la antigüedad, en una ciencia que «sabía más, aunque conociera menos»; el punto común de esa ciencia del pasado y aquella que necesariamente se impondría en el futuro era la búsqueda de una ley única, de una ley que sintetizara el funcionamiento de todos los fenómenos del universo. Hay aquí un curioso monismo espiritualista, dado que no se niega la ciencia por su oposición a la religión, sino que se aspira a un sistema de síntesis:

La Ciencia ingresa también, por su parte, a este gran movimiento. Sin quererlo, y aún sin notarlo, el materialismo ardoroso cambia de dirección. La Ciencia oficial aspira a la síntesis, y sus diversos ramos tienden a fundirse, determinándose por una sola ley. Cuando la ciencia encuentre esta ley, afirmará a Dios implícita y explícitamente... (1898a:168)

(...)

La teosofía aspira a la síntesis, demostrando, en moral, el origen común de todas las religiones; en ciencia, la ley única que engloba todos los conocimientos; en sociología, la solidaridad, que será el triunfo definitivo de la paz. (176)

Lugones dedicó buena parte de este ensayo a demostrar cómo las últimas conclusiones de la física sobre la materia y la fuerza (la energía), o de la biología sobre el desarrollo de los organismos, tendían a confluir hacia esa ley sintética, que se basará en la analogía y en la armonía de los contrarios. No obstante, no era la ciencia moderna, en su estado atomizado y precario de la época, la que llegaría a ese estadio, sino la ciencia llamada «oculta», esto es, la Ciencia de los teósofos.

Esta defensa explícita de un modo alternativo de conocimiento al método positivista, que contemplaría también a la moral y la belleza, continuará profundizándose en las colaboraciones subsiguientes. Así, en «Nuestro método científico», Lugones presenta los principales fundamentos de la ciencia teosófica, cuyo modelo a seguir — su «ciencia madre»— es la matemática. El método mismo de la ciencia teosófica es la ley de analogía, resumida bajo la frase «lo que está arriba es lo mismo que lo que está abajo». De ello, según Lugones, resulta que «el secreto de la constitución del Universo está en cualquier parte del mismo» (1900b:55-56). Hay aquí una clara confluencia entre la figura sinestésica de los simbolistas europeos y su uso estético de la analogía (o correspondencia), con la «ley» de la analogía de los teósofos, una confluencia de fuerte pregnancia en Lugones dada su participación en sendos ámbitos, la tradición literaria de sus inicios como poeta y esta forma del ocultismo moderno.

La convicción de Lugones es tan fuerte, que no duda en afirmar que la ley de la analogía ya contaba con la consideración de «los dos espíritus indiscutiblemente más vastos y profundos de la ciencia contemporánea», Darwin y Spencer, quienes habrían razonado analógicamente muchas conclusiones de sus teorías. Si bien en estos cuatro ensayos (que originalmente fueron conferencias) Lugones presenta sus argumentos como «el silabeo de un estudiante» (190ob:61), es claro que se coloca en un lugar de autoridad suficiente como para discutir de igual a igual con los científicos «materialistas» y vaticinar el futuro de las ciencias. Asimismo, adelanta aquí la estrategia discursiva de incrustar matrices teosóficas en la obra de autores medulares para las ciencias decimonónicas, como Darwin y Spencer. 
Durante los años en que escribió estos ensayos para Philadelphia, Lugones ya había empezado a publicar sus primeros relatos fantásticos, sus primeras fantasías científicas en las que lo ocultista se hibridizaba con lo material, en diarios como Tribuna, El Tiempo, El Diario, Caras y Caretas, y la propia revista Philadelphia. A diferencia de Bunge, no hay contraste alguno entre los argumentos de sus ensayos y los temas de sus cuentos. Muy por el contrario, sus presupuestos coinciden tanto que, por momentos, es difícil determinar el grado de ficción que Lugones le atribuía a su narrativa. Muchos de estos relatos conformaron luego el libro Las fuerzas extrañas, en el que se sumó «Ensayo de una cosmogonía en diez lecciones», una especie de marco cosmogónico para los casos sobrenaturales que presentaban los relatos, pero que también era, atendiendo a los futuros ensayos de Lugones, una cosmogonía personal que albergaba una voluntad de verdad y de trasmisión del conocimiento. Es posible rastrear en este ensayo imágenes, conceptos y genealogías que aparecerán tanto en su ficción como en su prosa no ficcional; y en ocasiones, como veremos más adelante, esos fragmentos aparecerán directamente citados como voz de autoridad.

En efecto, una década más tarde, reaparecen argumentos de sus relatos y de su «cosmogonía» cuando la Sociedad Científica Argentina le encarga a Lugones un ensayo en homenaje al palentólogo argentino Florentino Ameghino: el Elogio de Ameghino, publicado en 1915. Allí, Lugones rinde un homenaje ciertamente particular al sabio: si bien enumera sus obras, reconstruye parte de su biografía y da cuenta de su reconocimiento internacional (y de su relativo reconocimiento nacional), en gran parte del libro se apropia de sus teorías para proyectar con ellas derivas teosóficas de dudosa correspondencia con el pensamiento de Ameghino.

En sintonía con los ensayos de Annie Besant, sucesora de Blavatsky en la conducción de la Sociedad Teosófica, Lugones afirmará que la humanidad nada comparte en su pasado evolutivo con el resto de los animales sino que, por el contrario, ha seguido un camino evolutivo único, acorde a su superioridad espiritual. ${ }^{10}$ Ameghino nunca sostuvo idea semejante, tan alejada de la teoría de Darwin, pero Lugones, amparándose en su carácter de «estudiante», sin «una reputación científica que cuidar» (1915:7), se embarca en una ficcionalización de nuestro origen como especie, inspirado en lo que llama «la belleza espiritualista» del libro Filogenia de Ameghino (45). De a poco, la primera persona de Lugones va avanzando en el texto, y donde antes leíamos glosa de las teorías del paleontólogo, pasamos a leer lo que, en nota al pie, Lugones admite como una «digresión quizás excesiva» (164), en la que termina afirmando que descendemos de seres mitológicos.

El ejemplo más cabal de esta ficcionalización es la reconstrucción de la estirpe de los humanos, reconstrucción que deriva, como es frecuente en Lugones, en el relato mítico de los orígenes: el ensayista sostiene que las teorías filogenéticas de Ameghino:

nos permiten suponer que seres inteligentes análogos a nosotros, sino del tipo humano, han podido habitar la tierra desde el comienzo de la creación orgánica. (...) El ser primitivo debió consistir en una especie de sencillo ganglio cerebral. (...) Primero, sería nada más que un cerebro, el cual [sic] habría ido creándose los organismos materiales o «cuerpos» que le servirían de instrumento y de soporte; pues al decir «hombre», no me refiero al actual organismo humano, sino al ser inteligente, que, de tal modo, resultaría nuestro progenitor más directo. (57)

La reconstrucción es por lo menos curiosa, por no decir delirante, y si bien es cierto que en el prólogo a su obra Filogenia, Ameghino se cuida de aclarar que la banalización del transformismo 
darwinista cae en el grosero error de pensar que los monos actuales son nuestros verdaderos ancestros, difícil sería encontrar una fantasía como la que nos presenta Lugones. Sin embargo, la hiperbolización que Lugones hace del rol del cerebro en nuestra evolución no se detiene en esta cita, sino que páginas más adelante, se extiende hacia una reescritura de la ley de adaptación al medio basada en la inteligencia: para Lugones «todos los seres vivos son más o menos inteligentes, es decir, que comprenden e intentan comprender el plan de la vida con relación a su prosperidad individual» (58). Por ende, la superioridad evolutiva del hombre residiría en su mayor inteligencia para la adaptación, y esta premisa también parece justificar que la forma humana haya sido no sólo la más antigua de la tierra sino también la más pura, la más inmune a filtrar en su linaje eslabones bestiales. En este sentido, Lugones resuelve de forma antagónica a la de Bunge la valoración de esa distinción humana —la inteligencia—; lejos de ser un agente de la degeneración (negativa) de la especie, es su elemento originario y la razón de su superioridad evolutiva.

En cierta medida, el verdadero homenaje que rinde Lugones a Ameghino es convertirlo en un personaje más de Las fuerzas extrañas: un sabio bifronte, que participa tanto de la ciencia positivista como de la experimentación ocultista, y que postula una teoría de la evolución compatible con la cosmovisión teosófica. Ameghino sería así un colega del Dr. Paulin de «El Psychon» o del «sencillo sabio» de «La fuerza Omega». Asimismo, hay pasajes que parecen prácticamente copiados de relatos como «Izur», en el que se proyectan similares teorías alternativas sobre la evolución del hombre. La hipótesis que estructura el caso de «Izur», que efectivamente se corrobora en el cuento, aunque con trágicas consecuencias, es:

Los monos fueron hombres que por una u otra razón dejaron de hablar. El hecho produjo la atrofia de sus órganos de fonación y de los centros cerebrales del lenguaje; debilitó casi hasta suprimir la relación entre unos y otros, fijando el idioma de la especie en el grito inarticulado, y el humano primitivo descendió a ser animal. (1906:199)

La auténtica «fuerza extraña» de este relato es la voluntad de los monos petrificada en instinto, que el experimento súbitamente descongela y que hace emanar en esa voz que «ha permanecido sin hablar diez mil siglos» (209). Pero más allá de este efecto de terror que implica descubrir un espectro atávico de la humanidad habitando un animal, el relato monta toda su fantasía en una inversión de la evolución, en un alejamiento de lo animal como origen de nuestra especie y en la postulación del hombre como primer ser vivo. Curiosamente, en un pasaje del «Ensayo de una cosmogonía en diez lecciones» se afirma algo muy similar:

El ser planetario se había dividido en existencias. De éstas, las destinadas a formar el reino animal, eran inteligencias, es decir hombres, según correspondía, dado que el hombre era la fuerza superior en la animalidad, y debía, por lo tanto, aparecer primero. Todas las formas animales son derivados de aquellas células, ideaciones suyas, y la escala darwiniana se encuentra así totalmente invertida. El hombre es, pues, el progenitor del reino animal, explicando esto por qué repite las características de la serie zoológica durante su vida intrauterina; argumento el más poderoso del darwinismo para demostrar que es la síntesis inversa de toda esa serie. (276)

Así, lo que en el marco del libro de 1906 pareciera ser una correspondencia entre el argumento 
de un cuento fantástico, «Izur», y el "cosmocuento» del final, que da una especie de soporte cosmogónico a las invenciones (García Ramos:64), se revela en cambio como un nexo integrado a una red más amplia, compuesta por las concepciones teosóficas sobre la evolución del hombre, ajena a la evolución del resto de las especies, y las variaciones personales del teósofo Lugones, ensayadas indistintamente en textos ficcionales y no ficcionales.

Por otra parte, cabe señalar que Miguel de Azúa y Diego Hurtado de Mendoza también detectaron similares intertextualidades entre la ficción y los ensayos, a propósito de El tamaño del espacio. Ensayo de psicología matemática (1921), versión en libro de la conferencia que Lugones había pronunciado, un año antes, en la Facultad de Ciencias Exactas, Físicas y Naturales de la UBA. El texto de Lugones buscó ser una intervención sobre la concepción del espacio acorde a «los principios de la relatividad» de Albert Einstein (Lugones 1921:18) y, al igual que en el caso de Elogio de Ameghino, se detecta la incrustación de una cosmovisión teosófica en la materia que supuestamente buscaba divulgar (y sobre la que, a juzgar por los autores, Lugones comprendía muy poco). Nuevamente, ante una audiencia con formación en ciencias, esto es, los estudiantes y profesores de la Facultad, Lugones se erige en enunciador legitimado por su erudición y por su lugar en la cultura nacional (el triunfo de su «operativo», acorde a la idea de Terán), pero lo cierto es que no deja de ser desconcertante, para la mirada actual, que un escritor fuese el mejor exponente para hablar sobre las complejas y novedosas postulaciones de un físico como Einstein."

Luego de observar la combinación, en el ensayo, «de un despliegue de supuesta erudición científica y sutileza filosófica», con «una retórica hipnótica y grandilocuente» (2006:240), De Azúa y Hurtado de Mendoza señalan, en efecto, que aquí Lugones también vuelve a la cosmogonía de Las fuerzas extrañas para leer la relatividad y las postulaciones sobre el espacio de Einstein. O, en sus palabras, «la cosmología einsteniana es absorbida, sincréticamente, en la doctrina teosófica del “Ensayo de una cosmogonía en diez lecciones"» (2005:253). Y concluyen:

El tamaño del espacio, la conferencia que fue aplaudida por un público entusiasta de estudiantes de ingeniería y matemáticas, fue no sólo la promulgación de ideas de Einstein sino y fundamentalmente, una exposición teosófica. Ésta fue la segunda oportunidad en que Lugones promulgó estas ideas. En la primera lo hizo con la excusa apenas velada de la ficción. Para la segunda, eligió la tribuna científico-profesional. El análisis de los contenidos de ambos textos — que podía continuarse — demuestra que el segundo, el de 1920, depende del de 1906. Lugones fue consistente consigo mismo. Mientras en el «Ensayo» nos brinda su doctrina esotérica, El tamaño del espacio expone la versión exotérica de la misma, bajo la forma de una conferencia científica. Leída desde el punto de vista de la cosmogonía de 1906, la conferencia se revela como una reelaboración en la que se integran los últimos datos de la ciencia positiva a una matriz retórica ya constituida. (253)

En cierta medida, el núcleo duro de este ideario se había fijado ya en Lugones entre su tempranísima iniciación en la teosofía, a mediados de 1898 con su ingreso a la Rama Luz de la Sociedad Teosófica, y la publicación de Las fuerzas extrañas, ocho años después. Es en ese lapso cuando Lugones encuentra su propia cosmogonía (eminentemente discursiva), a partir de la cual erigir una enunciación autorizada en materia de arte, religión y ciencia. Acorde al sincretismo y la búsqueda de integración de las disciplinas que caracterizaba a la teosofía (al menos, en sus aspiraciones), Lugones veía en el arte, puntualmente en la literatura, una forma de conocimiento tan válida como 
la del método positivista. Por eso Lugones cita párrafos de su «Ensayo de una cosmogonía en diez lecciones» en el Elogio de Ameghino o repite lo postulado allí sobre la finitud del espacio en El tamaño del espacio. Sin solución de continuidad, el intelectual teósofo hace uso del amplio espectro de géneros discursivos para experimentar, como los científicos-ocultistas de sus cuentos, con la palabra y arribar así a la verdad. Estas pulsiones se extienden incluso hasta la reedición de Las fuerzas extrañas en 1926, cuando el autor agrega una "Advertencia» en la que, con total impunidad, avisa:

\footnotetext{
Algunas ocurrencias de este libro, editado veinte años ha, aunque varios de sus capítulos corresponden a una época más atrasada todavía, son corrientes ahora en el campo de la ciencia. Pido, pues, a la bondad del lector la consideración de dicha circunstancia, desventajosa para el interés de las mencionadas narraciones. (1926:95)
}

Difícil sería identificar qué elementos de este libro de relatos pudieran haber sido corroborados en 1926 o aun décadas más tarde. Acaso esta jactancia dialogue con esa idea presente en el Epílogo de El tamaño del espacio, en el que se insinúa que Lugones se anticipó al propio Einstein en su afirmación de que el espacio es finito. El Epílogo cita una nota del diario La Nación de enero de 1921, que reproduce a su vez un telegrama de un diario alemán, en el que se comunica la «nueva» conclusión de Einstein, cuya anticipación por parte de Lugones sería prueba el libro mismo.

Vemos, así, que en Lugones no sólo es posible reconstruir una idea de Ciencia en mayúsculas homologada a la cosmovisión teosófica, sino también un rol asignado a sí mismo dentro del campo científico (y por extensión, dentro del campo cultural en general) como médium comunicador de una verdad que es, en última instancia, espiritual.

\section{Actos de fe}

A pesar de sus diferencias (en el contenido, el grado de elaboración y su impacto en la época), leo las intervenciones de Bunge, Becher y Lugones dentro del amplio espectro del cientificismo argentino. Entiendo, aquí, al cientificismo como el término que engloba las prácticas y discursos que buscaron legitimarse como "científicos» combinando una férrea fe en las ciencias con una apropiación laxa de metodologías, teorías y conceptos de un variado espectro disciplinar. En el cientificismo primó más una voluntad de ciencia, que el efectivo desarrollo de una disciplina científica. En esa voluntad, se combinaron proyecciones a futuro, a veces partícipes de la utopía, y sincretismos diversos, en los que tuvieron lugar las superposiciones de la religión con el conocimiento secular, del «más allá» — la ultratumba, lo sobrenatural, el espíritu—con el «más acá» de la vida material, las inquietudes espiritualistas y filosóficas sobre la moral, el alma y la inteligencia con las exigencias metodológicas del positivismo.

Emilio Becher, en sus años espiritistas, enunció el deseo más optimista del cientificismo: que las ciencias lograsen descifrar los fenómenos del espíritu, del "psiquismo» y de las fuerzas ocultas de la naturaleza, y por fin probasen, con los propios métodos positivistas, la existencia de la dimensión trascendente de la vida. El bello oxímoron sostenido por Becher y por una zona del espiritualismo de entresiglos es la comprobación material de las creencias o, dicho en otros términos, el surgimiento de creencias razonadas que lograsen cohesionar la vida social sin caer en los dogmas y la obediencia de las religiones tradicionales.

Carlos Octavio Bunge, por su parte, desplegó estrategias que podríamos llamar «asertivas» 
en sus ensayos sobre psicología, sociología y derecho; pero en sus ficciones, en las fantasías científicas analizadas aquí, pareció asomarse melancólicamente sobre el terreno spenceriano de lo incognoscible. Con la creación de esa sirena que se niega a ser estudiada científicamente para no romper el «juguete» del Ideal, Bunge ejerció su imaginación cientificista (la sirena existe y podría ser estudiada) pero plasmó también un miedo espiritualista: perderlo todo a manos de la secularización del conocimiento.

En una pulsión opuesta, Lugones espiritualizó toda forma de conocimiento, al punto tal de concebir la ciencia «materialista» (el término es de época) dentro del marco mayor de la Ciencia teosófica, que ofrecía todas las respuestas existenciales, ontológicas y cosmogónicas que aquella se negaba siquiera a considerar. Si retomásemos la figura de la sirena, mencionaríamos el significativo final de su relato «El origen del diluvio. Narración de un espíritu», en el que una médium logra obtener la materialización de una pequeña sirena, que aparece muerta, «irradiando mortalmente su blancor» (1906:180), en el baño de un hogar moderno. Tras una comunicación con un espíritu de un tiempo remoto, en el que "esbozos de hombres» (174) fantasmales habitaban, surge la prueba material que conecta la antigüedad mítica con el tiempo presente: una sirena hermosa y perfecta en sus formas, que es probablemente quien ha narrado toda la historia. En el caso de Bunge, la sirena debe permanecer intocada, porque de lo contrario el equilibrio entre ciencia y mística se perdería. En el caso de Lugones, la sirena aparece como prueba contundente de que la única verdad está en la mitología, en la poesía, en una cosmogonía espiritualista. Para Lugones, el espíritu precede a la materia, siempre. Su cientificismo fue, así, el rodeo retórico que encontró exitosamente en la bibliografía teosófica para legitimar su propio discurso y, en simultaneidad, fagocitar a la ciencia moderna.

\section{Notas}

1 El trabajo fue financiado por la Universidad de Buenos Aires. Programación Científica (2014-2017). Ubacyt 20020130200191BA. «Textos recobrados en la prensa argentina (1870-1940)».

2 He trabajado puntualmente la presencia del ideario teosófico en los ensayos del Centenario de Lugones en Quereilhac 2008 y 2016. Véase, también, sobre el tema: De Asúa y Hurtado de Mendoza 2005:239-298, y Salazar Anglada 2000:601-626.

3 La biografía intelectual de Becher fue abordada por Eduardo Cárdenas y Carlos Payá 1979; entre los recientes aportes se cuentan Rey 2005:1-18, y Dalmaroni 2006:153-163.

4 Respecto de Lugones, Dalmaroni ha señalado atinadamente el "pacto de mutua conveniencia» entre ciertos intelectuales y el Estado argentino a comienzos de siglo XX, pacto que, paradójicamente, fue engranaje estructural del proceso de autonomización de la literatura y de la profesionalización del escritor en este país. Así, algunos escritores «reclaman e imaginan su propia justificación social en términos de la funcionalidad que representan específicamente para el Estado modernizador a cuyas demandas responden mientras imaginan que las diseñan; ciertos literatos, que ya no son generales, ministros, presidentes ni embajadores, se hacen pedagogos del nacionalismo del Estado o de los saberes del buen gobierno para convertirse en los escritores que demanda el arte y que el mercado - suponen- debería promover» (2006:35). En este sentido, recordemos el puesto de Inspector de enseñanza que ocupó Lugones durante el roquismo (equivalente a un Ministro o Secretario de Educación), los ensayos por encargo gubernamental (como El imperio jesuítico), entre otros roles. En el caso de Bunge, cabe recordar su desempeño en las cátedras de la Facultad de Filosofía y Letras, y en la Facultad de Derecho de la Universidad de Buenos Aires, y la publicación de un texto como Nuestra Patria, pensado para la escuela primaria. Cfr. Nosotros, año XII, $\mathrm{n}^{\circ}$ 3, julio de 1918 (Número homenaje a Carlos Octavio Bunge) y Terán 2000:135-206.

$5 \mathrm{Al}$ respecto, véase Rojas 1938 y la lúcida vuelta de tuerca a esta figura en Dalmaroni (153-163).

6 Para una ampliación de la caracterización de la «fantasía científica» véase Gasparini:119-147 y Quereilhac 2016:161-175. 
7 Hay otros pasajes en el relato que remiten a la moral católica: en relación con la alimentación de los hombres primitivos, se dice: «La carne es entonces, como dije, el pecatum originale» (Bunge 1908:73).

8 «La ciencia es la gloria, la fuerza y la alegría del siglo XIX. Armada con el método experimental (...), desembarazada de todos los entusiasmos religiosos, de todo prejuicio de espiritualismo, ha aclarado todos los misterios, ha descifrado los enigmas, ha conocido todas las luchas, ha explorado todos los campos» (Becher 1901:419).

9 En Philadelphia, se les da la calurosa bienvenida a tres jóvenes «distinguidos por su talento», entre los cuales estaban Lugones y Alfredo Palacios. El tercero pudo haber sido José Ingenieros, quien al poco tiempo colaboró con un ensayo, pero sin acompañar su firma con las siglas M. S. T. (miembro de la sociedad teosófica). La ausencia de las siglas y la falta de nuevas colaboraciones permiten dos inferencias: o Ingenieros no era esa tercera incorporación; o su vinculación con la Rama duró muy poco tiempo (s/f —1898 — «La Rama Argentina Luz». 101-105).

10 «El alma del hombre viene de arriba, no de abajo; ella no es el desenvolvimiento de un germen de la naturaleza bruta; es el foco en el cual son concentrados los rayos del Espíritu, del que ella es reflejo» (Besant:248).

11 En el marco del Simposio Internacional «Ciencia, cultura y modernidad en América Latina», organizado en abril de 2016 en Buenos Aires por la red Science in Text and Culture in LatinAmerica (AHRC-funded; University of Cambridge), pregunté a Miguel de Asúa cuál era la razón por la cual la Facultad de Ciencias Exactas, Físicas y Naturales convocaba a Lugones, un poeta, un escritor, un intelectual con formación humanística, para hablar de la relatividad. Su respuesta (que no puedo reproducir en términos literales, pero que espero recordar sin demasiadas distorsiones) fue que Lugones era un representante de la cultura, un sujeto con la formación retórica adecuada para dar conferencias y para convertir su discurso en un acontecimiento cultural. La respuesta de de Asúa fue iluminadora, en tanto mostró cierta vacancia dentro del campo científico de la época de una figura legitimada en la «cultura», así como el amplio margen de tolerancia para las derivas espiritualistas de Lugones (que ya se habían puesto a prueba en sus conferencias sobre el Martín Fierro de 1913).

\section{Bibliografía}

AA. VV. (1918). Nosotros. Número Homenaje a Carlos Octavio Bunge, (XII)3, 365-379.

Ameghino, Florentino (1928). Conceptos Fundamentales. Buenos Aires: Jackson.

Arnould, Arthur (1898, 7 de agosto). «Ciencia teosófica». Philadelphia, 17-20.

Becher, Emilio (1900a, 23 de septiembre). «Cristianismo y espiritismo». Constancia, 299-300.

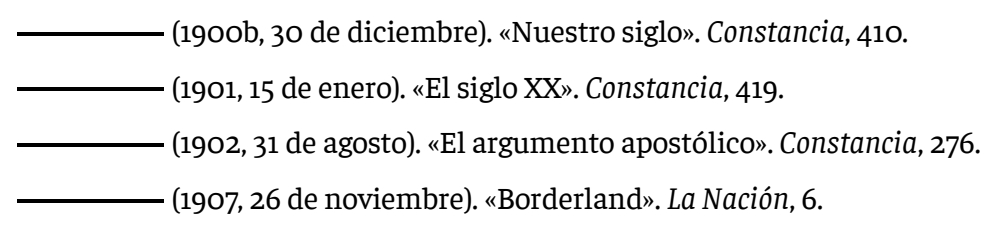

Besant, Annie (1899, 7 de febrero). «La evolución del hombre». Philadelphia, 246-250.

Bunge, Carlos Octavio (1903). Nuestra América. Buenos Aires: Moen y hnos, 1911.

(1908). Viaje a través de la estirpey otras narraciones. Buenos Aires: Biblioteca de La Nación.

(1910). Nuestra Patria. Buenos Aires: Angel de Estrada.

Cárdenas, Eduardo y Carlos Payá (1979). Emilio Becher. De una Argentina confiada hacia un país crítico. Buenos Aires: Peña Lilo.

Chiappori, Atilio (1907). Borderland. Buenos Aires: Biblioteca Nacional, 2015.

Dalmaroni, Miguel (2006). Una república de las letras. Lugones, Rojas, Payró. Escritores argentinos y Estado. Rosario: Beatriz Viterbo.

De Asúa, Miguel y Diego Hurtado de Mendoza (2005). «Relatividad y literatura en Argentina» y «Epílogo».

Imágenes de Einstein. Buenos Aires: Eudeba, 239-298.

Delcos, Mario (pseud. Carlos O. Bunge) (1908, 15 de febrero). «iUna sirena en Mar del Plata!». Caras y Caretas,

489. 
Gálvez, Manuel (1918). «El escritor y el hombre. (Datos para los biógrafos de Carlos Octavio Bunge)». Nosotros, (XII)3, 365-379.

García Ramos, Arturo (1996). «Introducción» a Leopoldo Lugones. Las fuerzas extrañas. Madrid: Cátedra, 9-91. Gasparini, Sandra (2010). «La fantasía científica. Un género moderno», en Alejandra Laera, directora. El brote de los géneros. Historia crítica de la literatura argentina. Tomo 3. Buenos Aires: Emecé, 119-147.

González, Horacio (1999). Restos pampeanos. Ciencia, ensayo y política en la cultura argentina del siglo xx. Buenos Aires: Colihue.

Lugones, Leopoldo (1897-1898). «Los climas del arte». La Quincena. Revista de Letras. Tomo 5, marzo-febrero, 310-314, 443-446.

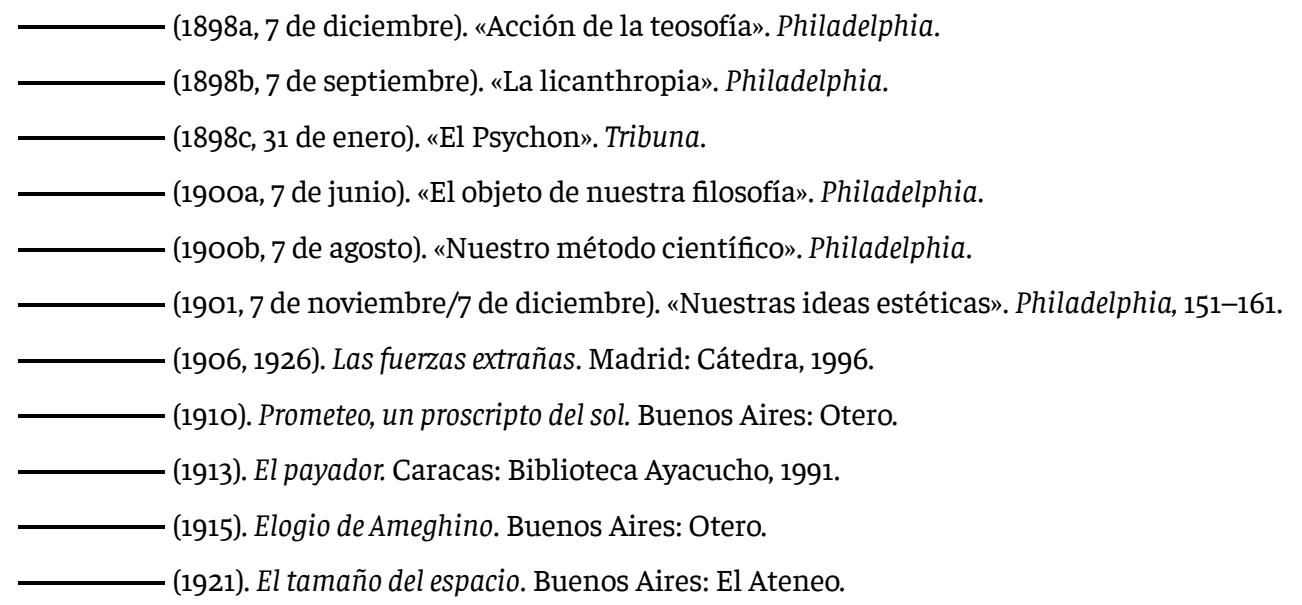

Mariño, Cosme (1963). El espiritismo en Argentina. Buenos Aires: Constancia.

Quereilhac, Soledad (2008). «El intelectual teósofo: Leopoldo Lugones en Philadelphia (1898-1902)». Prismas. Revista de historia intelectual. Bernal: UNQ, 12, 67-86.

- (2010). La imaginación científica. Ciencias ocultas y literatura fantástica en el Buenos Aires de entresiglos (1875-1910). Tesis doctoral. Buenos Aires: Universidad de Buenos Aires. Web.

(2016). Cuando la ciencia despertaba fantasías. Prensa, literatura y ocultismo en la Argentina de entresiglos. Buenos Aires: Siglo XXI.

Quiroga, Horacio (1907, 13 de julio). «El almohadón de plumas». Caras y Caretas, 458.

(1909, 10 de julio). «La gallina degollada», Caras y Caretas, 562.

Rey, Ana Lía (2005). «Emilio Becher, espiritualismo y política en el cambio de siglo». Actas de $X^{\circ} J o r n a d a s$ Interescuelas /Departamentos De Historia. Rosario, 20-23 de septiembre.

Rojas, Ricardo (1906; 1917, 24 de diciembre). «La psiquina», La Novela Semanal, 6.

(1938). «Evocación de Emilio Becher», en Emilio Becher. Diálogo de las sombras. Buenos Aires:

Universidad de Buenos Aires, V-XLVII.

S/f (1898, 7 de octubre). «La Rama Argentina Luz». Philadelphia, 101-105.

S/f (1899, 7 de octubre). «Leopoldo Lugones». Caras y Caretas, 53.

S/f (1901, 24 de noviembre). «El espiritismo y la ciencia oficial». Constancia.

Salazar Anglada, Aníbal (2000). «Modernismo y Teosofía: La visión poética de Lugones a la luz de “Nuestras ideas estéticas"». Anuario de Estudios Americanos. Tomo LVII, 2, 601-626.

Sarlo, Beatriz y Carlos Altamirano (1983). «La Argentina del Centenario: campo intelectual, vida literaria y temas ideológicos». Ensayos argentinos. De Sarmiento a la vanguardia. Buenos Aires: Ariel, 1997.

Soler, Ricaurte (1979). El positivismo argentino. México: UNAM. 
Terán, Oscar (1993). «El payador de Lugones o la mente que mueve las moles». Punto de Vista. Buenos Aires, (XVI)47, 43-46.

(2000). «Carlos Octavio Bunge: raza y nación». Vida intelectual en el Buenos Aires de fin de siglo (1880-1910). Derivas de la cultura científica. Buenos Aires: Fondo de Cultura Económica, 135-206.

Thespis (pseud. Carlos O. Bunge) (1908, 8 de febrero-14 de marzo). «Viaje a través de la estirpe». Caras $y$ Caretas, 488-493. 